Integritas 2.3 (Fall 2013), pp. 1-13.

doi: $10.6017 /$ integritas.v2i3p1

\title{
The Making of the Modern Core: Some Reflections on the History of the Liberal Arts in Catholic Higher Education in the United States
}

\section{David Quigley}

Attention to historical developments, shifts, and even reversals in core curricula can alert us to the ongoing and dynamic tensions between foundations and innovation in Catholic higher education in the United States. Surveying two centuries of curricular and institutional development, this essay highlights some distinctively American dimensions of this story while recovering lost experiments in liberal arts education and assessing ongoing challenges to the liberal arts commitments of the contemporary

Catholic university. The particular institutional history of Boston College since its founding in 1863 will illuminate larger themes of change and continuity with particu-

lar interest in evolving and competing ideas about undergraduate core curricula.

The "transformation" project that Thomas Plante advanced and that Kevin Hughes helpfully refined ${ }^{\mathrm{I}}$ links up with a central idea that I've been wrestling with in writing this paper and in working on Boston College's Core. We're ever engaged in becoming a different kind of university, and I hope one that is more truly Catholic and Jesuit. When we adults think about the transformation of our students, there is at times a tendency to think that we-as faculty and administrators - are somehow agents of transformation

$1 \quad$ See Integritas 2.1 (Fall 2013).

David Quigley is a Professor of History and the Dean of both the College and Graduate School of Arts and Sciences at Boston College. Dr. Quigley teaches a wide range of undergraduate and graduate courses on the nineteenth-century United States and on political and urban history. His research to date has explored the history of race and democracy between the American Revolution and Reconstruction in local political cultures of New York. He is completing a new synthetic project, Last, Best Hope: International Lives of the American Civil War (Hill a Wang) and is editing both A Companion to American Urban History (Blackwell) and Busing in Boston: A Brief History with Documents (Bedford). 
for others. My sense is that for the "transformation" project to succeed, the adults in the community-individually and in institutional form-must be open to the possibility of our own transformation. It goes without saying that we live in an age of transformation in higher education. Crisis language abounds from the front page of the New York Times to the latest edition of The Chronicle of Higher Education. Is our business model sustainable? Are we internationally competitive? Are institutional boards too strong, or not strong enough? Where is technology leading us? Every day, it seems, one can find another doomsday prediction for our industry. And from my perch, the preferred area of concern over the last few years has been the liberal arts, and in particular the disciplines that constitute the humanities.

\section{My sense is that for the "transformation" project to succeed, the adults in the community-individually and in institutional form - must be open to the possibility of our own transformation.}

What unites our schools, and all of Catholic higher education in the United States, among other things, is our shared commitment to liberal arts education for all undergraduates, in our Colleges of Arts and Sciences as well as in our various pre-professional units. Some form of a "core curriculum" exists on many of our campuses, articulating a fundamental institutional commitment while also linking us powerfully to each other and to an enduring tradition. And yet, what I find so striking as a historian and as a dean is the diversity of core curricula, even within the membership of the Association of Catholic Colleges and Universities. Eight credit hours to over 50. All great books all the time on one campus, ever-changing service and experiential core offerings on others. A Chinese-menu approach offering a set of distribution requirements is the reality on too many campuses. Some of our sister institutions work hard to ensure that all undergraduates not only take the same core, but that they take the same courses and read nearly all the same texts. Diversity as much as commonality marks our commitment to the liberal arts.

And when one looks at the two-plus centuries of Catholic higher education in the United States, this variousness becomes even more striking. The distinctive liberal arts education at Georgetown in the early nineteenth-century bears only a distant relationship to the liberal arts education that all Georgetown students receive today. I would imagine that's the case on just about all of our campuses; as I'll explore in the second half of my remarks, that has certainly been the reality at Boston College. As Catholic colleges and universities, we define ourselves to a considerable extent by our liberal arts commitments, and those commitments appear in different forms, with different curricula and different institutional structures across space and time. 
This gathering's emphasis on "transcendent value" would seem to invite us to think of the timeless and ahistorical nature of the liberal arts in the Catholic university. This essay attempts to work against that grain, instead exploring the ways in which attention to historical developments, shifts, and even reversals can alert us to the ongoing and dynamic tensions between foundations and innovation in Catholic higher education in the United States. Surveying two centuries of curricular and institutional development, I'd like to highlight some distinctively American dimensions of this story while recovering lost experiments in liberal arts education and assessing ongoing challenges to the liberal arts commitments of the contemporary Catholic university. The particular institutional history of Boston College since its founding in I863 will illuminate larger themes of change and continuity with particular interest in evolving and competing ideas about undergraduate core curricula.

\section{The Core in the History of American Higher Education}

Let me begin with a brief survey of the broader landscape of American higher education in order to help clarify, I hope, some of the distinctive challenges facing Catholic institutions as we search for a more perfect core. From the founding of Harvard College in I636 until the final decades of the nineteenth century, the colonial and then earlynational colleges were devoted, above all else, to educating young men for the ministry. Down to the Civil War, American institutions sustained strongly denominational identities, and training in theology and moral philosophy were often central to the course of studies for all. There was no need to talk of a "core curriculum" across the first three centuries of American higher education, since there was such a consensus-at least at the institutional level_-as to what should be taught, and what young men were being trained to do.

Between the end of the Civil War and the era of the First World War, a series of transformations in higher education and in society more generally forced a profound rethinking of the undergraduate curriculum and led Americans, for the first time, to start thinking about something that could be called a core. The Lincoln administration in some ways sparked this age of educational transformation with the Morrill Act of I862, launching the nation's expansive network of public land-grant institutions. The United States experienced a great wave of educational institution-building in the final third of the nineteenth century, and access to colleges and universities was substantially expanded. No longer were colleges primarily training young men for the ministry. Men and women now appeared on campuses and pursued a wider range of studies in the practical arts and across the liberal arts.

As access to higher education expanded in these decades, many colleges and universities went through a disruptive period of institutional redefinition. George M. Marsden's I994 book captured this dynamic in the subtitle: From Protestant Establishment to Established Nonbelief. The rise of the modern research university reoriented higher education toward graduate and professional education, with universities elevating "research" as a defining value and abandoning, in most cases, an earlier faith-based 
institutional sense of self. The historian Julie Reuben writes of that era's "marginalization of morality" as an underappreciated dimension of the rise of the modern university. By the second decade of the twentieth century, a number of faculty members and university leaders came to voice concern about the broader changes in the nation's colleges and universities and especially about the diminished place of undergraduate education. ${ }^{2}$

In this era of transformation and crisis, one finds the beginnings of a national conversation about the idea of a "core curriculum." On different campuses, it was reflected in particular ways: distribution requirements, a new language of "general education," a defense of the liberal arts. A survey of the last century of American higher education history indicates that core development and revision often accompanied great moments of crisis and transformation: the coming of World War One, the aftermath of the Second World War and the GI Bill, the cultural and political struggles of the I96os. Repeatedly, the nation's faculty, students, deans, and presidents turned to the core as both problem and potential solution in difficult times for individual colleges and universities.

Columbia University's last Ioo years are instructive in this regard. Under the leadership of President Seth Low, the school had moved uptown to Morningside Heights at the turn of the twentieth century. While Low helped shape Columbia as one of the nation's great research universities, he also expressed concern about the education of undergraduates in Columbia College. Between the I890s and I9I7, a series of experiments were attempted at Columbia in hopes of strengthening undergraduate education and providing coherence in a university that was growing increasingly decentralized. This era of institutional change culminated in I9I9's launch of the Contemporary Civilization course, Columbia's initial attempt to define a distinctive core experience for all undergraduates. At first a joint initiative of the departments of economics, government, history, philosophy, and sociology, Contemporary Civilization intentionally sought to force faculty outside of their areas of specialization. An early report made clear that "it will tend to break down those 'idea-tight' compartments in which learning too often isolates itself." 3

The fundamental goal of the course was to "introduce the students to the insistent problems of today through acquainting them with the materials of their situation: nature's resources and human nature and its recent history." In response to the experience of world war, Columbia committed to a core that linked Western civilization and contemporary social science. This wartime context informed early reflections on the course's launch, with one observer noting that the successful first year was largely due to the fact that "the war and its issues have made even boys thoughtful, and the social

2 George M. Marsden, The Soul of the American University: From Protestant Establishment to Established Nonbelief (New York: Oxford University Press, 1994); Julie A. Reuben, The Making of the Modern University: Intellectual Transformation and the Marginalization of Morality (Chicago: University of Chicago Press, 1992). 
unrest which has come with peace has intensified reflection."

The Columbia Core would evolve over the next several decades, emphasizing the great books and the reading of primary sources. A second year of studies was added by mid-century, and much of the last 50 years of the Columbia experience has been characterized by recurring struggles over the definition of the "canon." To this day, however, the commitment to a common core remains a defining feature of institutional identity at Columbia. Rooted in an earlier sense of crisis, Columbia's core aspires to establish a liberalarts foundation for all students' later studies in majors and across the curriculum.

The final third of the twentieth century was an era when many research universities and liberal arts colleges reduced or even eliminated earlier requirements in general education. The culture wars of the I960s and I970s played out in a range of ways on our campuses. Brown University, to take perhaps the most extreme example, moved to eliminate all requirements (beyond the major) in order to allow total freedom for students to pursue education by elective. Not many schools went quite as far as Brown, but many secular colleges and universities' curricula swung heavily in the direction of student choice and minimal requirements in those crisis years. While some of these trends played out on Catholic campuses, I would argue that one result of that era is that the distinctiveness of Catholic higher education, previously defined along theological and cultural lines, became more clearly tied to institutional commitment to the idea of a liberal arts core.

\section{The Core in Catholic Higher Education}

Turning to the Catholic aspect of our history, I should begin by noting that, of course, the liberal arts — and even something resembling a core-have been a central and defining part of Catholic higher education for a very long time. The medieval universities were organized around the liberal arts, most especially philosophy and theology, and the Catholic schools that rose up in the early modern period often emphasized the humanities and the arts in addition to other established and professional fields of study. As John O'Malley, S.J., has reminded us, the early Jesuit schools attempted to fuse the idea of the university with the values of the humanistic college. By the end of the sixteenth century, Jesuit educators had codified their evolving thinking about education in the Ratio Studiorum, a text that would shape centuries of Ignatian pedagogy around the globe with its clear articulation of the centrality of the liberal arts. ${ }^{5}$

Jesuit and other Catholic educators in Europe emphasized theological training while also requiring extensive training in classical languages and literature. History and philosophy helped round out humanistic education at many Catholic institutions.

As is clear in the many wonderful institutional histories of Catholic colleges and universities that I've been reading over the last few months, the European influence was

4 Columbia University Quarterly, October 1919, p. 333.

5 John W. O'Malley, S.J., "How the First Jesuits Became Involved in Education," in The Jesuit Ratio Studiorum: 40oth Anniversary Perspectives. Vincent J. Duminuco, S.)., Ed. (New York: Fordham University Press, 2000). 
profound in the early years on many of our American Catholic campuses. To take the local example, the Irish Jesuit John McElroy founded Boston College in I863 and was quickly followed by the Swiss Jesuit Johannes Bapst, who arrived in I864 and helped create the curriculum that would be taught for the rest of the nineteenth century. Notre Dame, Santa Clara, Fordham-the Catholic schools founded in the middle of the nineteenth century all bore the strong stamp of their European founders.

As my colleague Jim O'Toole has pointed out, this European influence had some not entirely positive results. Part of the local lore here at Boston College is that in the late-nineteenth century, Harvard's graduate schools' admissions committees would not admit Boston College graduates; generations of Eagles have told this story as a mark of Brahmin anti-Catholicism and the great struggles early Boston College graduates experienced. O'Toole emphasizes that the Harvard admissions officials had very good reason to turn down Boston College applicants, as the Jesuit school's curriculum down to the early twentieth century was substandard and more equivalent to secondary schools than to other New England institutions of higher learning. ${ }^{6}$

The history of the oldest of America's Catholic colleges-Georgetown-illuminates the complicated and not always successful evolution of liberal arts education on our campuses. Founded in 1789 , Georgetown at the end of the nineteenth century required three years of Greek and Latin, three years of sciences, and extensive training in philosophy and theology, culminating in Io hours in each area in the senior year. This unitary curriculum for all students was typical of that generation of Catholic schools, though the extensive emphasis on the natural sciences was somewhat unusual. The idea of a "major" was unheard of, and all students were to graduate with the bachelor of arts (requiring several years of Greek and Latin).

Fast-forwarding to the middle of the twentieth century, the development of schools separate from Arts and Sciences resulted in an increasingly diffuse undergraduate experience and the disappearance of anything that would resemble a common core. Particularly troubling to post-war Georgetown administrators was the drop-off in enrollments in classical languages. By I958, in the College of Arts and Sciences, Latin and Greek remained as requirements for the B.A. degree, but only Io\% of A\&S students fulfilled the requirement, with the large majority of students receiving several other bachelor's degrees. While Georgetown continued to require 25 hours of philosophy, a curriculum reform committee in that year sought to revise the entire undergraduate curriculum in hopes of providing "a unified body of knowledge and a common acquaintance with our culture"; that committee proposed to install a new set of distribution requirements, with humanities, social sciences, and natural sciences as organizing divisions.7

The most striking aspect of the late-I950's Georgetown discussion of the core was how long its aspirations went unfulfilled. As late as the I980s in response to national

6 James O'Toole, "Class Warfare," Boston College Magazine (Winter 2012).

7 Robert Emmett Curran, A History of Georgetown University, volume II (Washington, D.C.: Georgetown University Press, 2010), p. 342. 
critiques of higher education, a successor curriculum committee called for a universitywide core that would place emphasis on "skills, knowledge, and wisdom." As Robert Emmett Curran later wrote, "the ensuing mandated discussions produced a very lackluster response to the questions posed." The growing complexity of the university, internal divisions among faculty, and a broader questioning of the idea of core curricula, among other factors, helped to explain the demise of that attempt at formulating a coherent core for Georgetown. Curran concludes his history of the struggle for a core at Georgetown with the following lament: "The establishment of a core continued to elude the main campus." 8

To date, Georgetown College maintains an extensive set of general education requirements, and many required courses advance the university's distinctive Catholic and Jesuit mission. The struggles over a common core that Curran identifies are illustrative of the challenges faced by many Catholic schools in offering a rich and varied curriculum, in attracting and retaining the best students and faculty, and in balancing aspirations for excellence with a commitment to sustaining a strong sense of institutional identity and mission. These same challenges certainly recur here at Boston College, and I'd imagine on many other campuses.

\section{The struggles over a common core are illustrative of the challenges faced by many Catholic schools in offering a rich and varied curriculum, in attracting and retaining the best students and faculty, and in balancing aspi- rations for excellence with a commitment to sustaining a strong sense of institutional identity and mission.}

In the last generation, many of our Catholic campuses have developed or revised core curricula. The commitment to a core is often rooted in a desire to provide all students with a solid intellectual foundation rooted in the classics of Western culture while holding out the possibility of meaningful engagement with contemporary culture. There exists an interesting and fundamental tension between that enduring quest for certainty within a fixed curriculum and the never-ending search for a better way of delivering a Catholic core, for reaching a particular generation's undergraduates, and for engaging with the demands of contemporary society. The great strength of our Catholic cores lies in their variousness, ranging from the great books to experiential learning to extensive interdisciplinarity to only Western Culture to a disorienting cosmopolitanism. I'd suggest that Catholic higher education in America would be worse off if the range of cores was somehow narrowed in coming years.

8 Curran, p. 194. 
Before turning to the particular challenges Boston College has faced and continues to face in developing and offering a distinctively Catholic and Jesuit core curriculum, two statements made by the current superior of the Jesuits, Fr. Adolfo Nicolás, and his immediate predecessor, Fr. Peter-Hans Kolvenbach, bear consideration. In 2000, as part of Santa Clara's celebration of its sesquicentennial, Fr. Kolvenbach spoke on "The Service of Faith and the Promotion of Justice in American Jesuit Higher Education." His words have resonated across Jesuit higher education and they offer a particularly compelling way for us to think about the work in our schools and with our students. Fr. Kolvenbach's question that stands out for me, and to which I often return, concerns who we want our students to become:

\section{"If the measure of our universities is who the students become, and if the faculty are the heart of it all, then what is there left to say?" PETER-HANS KOLVENBACH, S.J.}

The best mark of the success of a Jesuit institution lies in who our graduates become after graduation. For me, any Catholic core must address how the sequence of liberal arts courses somehow contributes to the formation of a particular type of graduate. ${ }^{9}$

Three years ago in Mexico City, Fr. Nicolás spoke on "Challenges to Jesuit Higher Education Today." Perhaps his most memorable formulation pointed to a growing "globalization of superficiality" which requires a commitment on the part of Jesuit educators to "depth of thought and imagination." As all Catholic campuses explore how to teach about global concerns in an authentic and meaningful way, Fr. Nicolás's words point us toward the need to think more deeply about how we engage our students. A globalized core, if one can exist, must avoid the easy tendency toward "superficiality" and instead must aim for a profound sense of wholeness rooted in, yet at the same time pushing at the frontiers of, the Catholic intellectual tradition. ${ }^{\text {. }}$

\section{The Case of Boston College's Evolving Core}

The remainder of this essay will focus on my home institution, Boston College, and our collective commitment to a core curriculum. Allow me a brief personal digression. I arrived at Boston College in I998 as a new faculty member in the History Department, hired to teach American urban history and the era of the Civil War and Reconstruction. I had had no previous experience with a core, as my undergraduate institution only had

9 Peter-Hans Kolvenbach, S.J., "The Service of Faith and the Promotion of Justice in American Jesuit Higher Education," lecture at Santa Clara University, 2000.

10 Adolfo Nicolás, S.J., "Challenges to Higher Education Today," Conversations on Jesuit Higher Education: Vol. 40 (2011), Article 5. 
one required course (outside of the major) and my graduate institution took the general education/distribution requirements approach.

One of the great surprises of my I6 years at Boston College has been my growing commitment to the core. I volunteered to teach in it very early on in my time on campus, and I've always been struck by the satisfaction of being part of a larger project like the core. That said, I also grew restless with some of the limitations and missed opportunities in our current core, a curriculum that was last revised in I99I, and as Dean I had been working for several years to launch a conversation about our core. For the last year, I and the Director of our Institute for the Liberal Arts and the Dean of our Carroll School of Management have initiated a Core Renewal process and we are currently working with our President and Provost to pilot new core courses and experiences. We have a long way to go, but we're mid-stream on a fairly ambitious attempt at renewing the Boston College core.

Which leads me back to the history of our core. For much of our history, no one ever spoke of a core. Philosophy was the de facto major for most Boston College undergraduates through the I950s, and all students took extensive coursework across the liberal arts. The institution began to move toward a core in the post-war era; as professional schools expanded, the university grew, and the faculty became increasingly lay. Five years after Georgetown's attempt to install a new curriculum in I958, Boston College's President, Fr. Michael Walsh, S.J., convened a Committee on the Total Curriculum in I963. ${ }^{\text {II }}$ Walsh saw himself a modernizer and hoped to transform Boston College into a serious research university. He began a series of doctoral programs and initiated the nationalization of the student body. The undergraduate curriculum lay at the heart of his ambitions for the university. As the Committee on the Total Curriculum began its work in I963, Fr. Walsh wrote to his Provincial in hopes of securing Rome's support for his reforms. Let me quote at length from Walsh's correspondence with the Provincial:

In an effort to provide a more scholarly and reflective setting for the college experience, it is our hope to cut the present 48 -course schedule to 38 courses, with five in each of the first three years and four in the senior year (per semester). Within this less course-burdened schedule, there has also been an attempt to provide for the freedom to take advanced electives in the traditional humanistic areas such as English, languages, and history, while at the same time giving adequate but not overbalanced attention to the student's major area of study and to preparation for graduate study.

In the ensuing back-and-forth, the Provincial posed a series of questions about the curricular revisions that Walsh seemed to have in mind. Walsh's final response to the Provincial was illuminating:

As a preface, let me say, since several of your questions focus on our requested

11 Charles F. Donovan, S.J., David R. Dunigan, S.J., and Paul A. FitzGerald, S.J., History of Boston College: From the Beginnings to 1990 (Chestnut Hill, Mass.: The University Press of Boston College, 1990), p. 297. 
reduction of courses required in the core curriculum, that we are keenly concerned to preserve the integrity and spirit of the Jesuit liberal arts tradition as far as this can possibly be done within a reduced course load. The key factor here, as is obvious, is our conviction-a conviction not unique to us among Jesuit colleges - that our students are carrying a course load that is too heavy. [Goes on to explain many schools moving to four courses per term, etc.] It is, therefore, not by any means for the purpose of lessening the effectiveness or contribution of the liberal arts that the suggested reductions are made, but in order to provide what we sincerely feel is a schedule of studies better fitted to the talents and previous education of our current students, more consonant with the present trend in higher education to place more responsibility upon the individual student for self-direction in his education, and better adapted to the realistic needs of today's undergraduates as regards preparing for graduate education.

What's striking here is Walsh's sense that moving toward a core at Boston College was a way of preparing students for the nation's best graduate schools, of supporting the free choice of undergraduates, and most strikingly, a way of making Boston College more like elite, secular schools. ${ }^{\text {I2 }}$

Adding to the surprising nature of Walsh's work in $196_{3}$, he was assisted throughout the I963-I964 academic year by a special outside advisor, Dr. Victor Butterfield, then President of Wesleyan University in Connecticut. Across a college presidency that ranged from I943 to I967, Butterfield was a leader in liberal arts education in post-war America. In a series of letters to Fr. Walsh, Butterfield encouraged the development of a Boston College core as part of a broader agenda that challenged the rise of a specialized research faculty.

Among his many suggestions and complaints, let me share three of Butterfield's pieces of advice for the Jesuit President of Boston College:

I. It seems to me that the heavy emphasis on departmentalization symbolizes and encourages a kind of specialization that we don't want. It tends to exclude or discourage cultural breadth and range and intellectual variety and versatility in scholars and teachers, and puts them in the false position of insisting on such qualities in their students while they don't have them themselves. It also limits the possibilities for a genuine community of scholars, and tends to weaken rather than strengthen the kind of intellectual climate or atmosphere that is so vital in the life of scholars and the education of students.

2. Research is now a loaded word with faculty members, and to be at all critical is apt to put you in the position of seeming to be against the whole idea. I wish there were a better word for it, and that we could conceive of our faculty members as being constant "learners" as well as teachers. Perhaps the word "research" has this connotation for some, but I doubt for many since it has become a kind of 
fetish, and its essence is symbolized in both academic and popular mind by scientific research.

3. Most faculty members should be good with the average undergraduate, though it is important to recognize those teachers who are especially good with majors or with graduate students. Some faculty people have to be good administrators and like it. Some are especially good to carry the educational adventure to the extramural world, and this is important too. A faculty must, in fact, in the right balance reflect collectively the various functions of the institution, and I think we have to stay aware of this and be careful not to apply the same formula to all faculty appointments although of course the dominant type should be the broad, cultivated scholar-teacher type who is thoroughly competent in a special field.

Butterfield's advice wasn't all acted upon, but Fr. Walsh and the Boston College faculty of the ig6os developed an extensive core curriculum that marked a major change from the earlier undergraduate experience. There was a sustained battle over the theology requirement in the late I96os as the credit hours required of all students dropped first from twelve to nine and then eventually down to six (where it remains four decades later). ${ }^{\mathrm{I3}}$

\section{The great value of the core in a Catholic context is the opportunity to shape and sustain a common intellectual conversation across campus, and across generations.}

In that battle and on into the early I970s, it remained unclear who had authority over core, with the University Academic Senate and the Arts and Sciences Educational Policy Committee claiming oversight authority over its emergence.

A University Committee on Liberal Education (U.N.C.L.E.) emerged in I969-I970, hoping to clarify issues of governance and advance a coherent core vision for the entire university. Despite its wonderful acronym, U.N.C.L.E. disappeared soon after its creation but not before leaving behind one long-term and transformational legacy in the form of the PULSE program, Boston College's long-standing service learning core offering that bridges courses in philosophy and theology and extensive service in Boston-area social service settings.

Twenty years later, between I989 and I99I, Boston College faculty and students engaged in a sustained process of reflection on the strengths and weaknesses of the core that had emerged from the I960s and early I970s. Some irrational features of the existing core were quickly identified. For instance, there was a requirement in EITHER math or the arts. Cultural diversity was identified as a major gap in the existing core (reflecting broader national trends in American higher education in the I980s). By I99I,

Donovan et al., 342-343. 
a new 42-credit core was approved with a new governance structure, the University Core Development Committee, created to oversee the core and to support new course development. While there was some initial experimentation and innovation within the core in the early I990s, any spirit of innovation and creativity had largely disappeared by the time I arrived on campus in the late I990s. The UCDC came to serve a role as bureaucratic gatekeeper, and the possibility of a broader campus conversation about the core and the university's broader mission never came to fruition.

I could now go on for the rest of the day on lessons learned from the Core Renewal process of the last two years. I'll spare you this exhaustive litany, but let me conclude with a few thoughts from a historian dean:

I. The great value of the core in a Catholic context is the opportunity to shape and sustain a common intellectual conversation across campus, and across generations.

2. The variousness of cores across our campuses is a strength of Catholic higher education, even as the range of programs and structures demands that we question just what it is that we mean when we talk about the core.

3. The core always exists in a place of tension between a foundational sense of certainty and an energizing sense of searching.

4. Let me add a fourth and final endnote here, building on one of Kevin Hughes's comments. His description of the attempt to develop a meaningful fourth hour for his humanities classes at Villanova University strikes me as critical to the development of a more Catholic core for the next generation of students. How can faculty, in authentic collaboration with partners in Student Affairs and University Mission \& Ministry, help students to break down the ever-deepening rift between students' classroom selves and the lives they live in dorms, in the evenings, and on weekends? Put more succinctly, how might we develop our own versions of the fourth hour that encourage students and faculty alike to think about our academic vocation as calling us toward an enriching wholeness? 


\section{Bibliography}

Buckley, Michael J., S.J. The Catholic University as Promise and Project: Reflections in a Jesuit Idiom. Washington, D.C.: Georgetown University Press, I998.

Curran, Robert Emmett. A History of Georgetown University. Volumes II and III. Washington, D.C.: Georgetown University Press, 2010.

Delbanco, Andrew. College: What It Was, Is, and Should Be. Princeton: Princeton University Press, 2012.

Donovan, Charles F., S.J., David R. Dunigan, S.J., and Paul A. FitzGerald, S.J. History of Boston College: From the Beginnings to 1990. Chestnut Hill, Mass.: The University Press of Boston College, I990.

Gleason, Philip. Contending with Modernity: Catholic Higher Education in the Twentieth Century. New York: Oxford University Press, I995.

Kolvenbach, Peter-Hans, S.J. "The Service of Faith and the Promotion of Justice in American Jesuit Higher Education," lecture at Santa Clara University, 2000.

Leahy, William P., S.J. Adapting to America: Catholics, Jesuits and Higher Education in the Twentieth Century. Washington, D.C.: Georgetown University Press, I99I.

Marsden, George M. The Soul of the American University: From Protestant Establishment to Established Nonbelief. New York: Oxford University Press, I994.

Menand, Louis. The Marketplace of Ideas: Reform and Resistance in the American University. New York: W.W. Norton and Co., 20Iо.

Nicolás, Adolfo, S.J. “Challenges to Higher Education Today,” Conversations on Jesuit Higher Education: Vol. 40 (20II), Article 5.

Nussbaum, Martha C. Not for Profit: Why Democracy Needs the Humanities. Princeton, N.J.: Princeton University Press, 20 о.

O’Malley, John W., S.J. “How the First Jesuits Became Involved in Education,” The Jesuit Ratio Studiorum: 4ooth Anniversary Perspectives. Vincent J. Duminuco, S.J., Ed. New York: Fordham University Press, 2000.

The First Jesuits. Cambridge, Mass.: Harvard University Press, I993.

O’Toole, James. “Class Warfare.” Boston College Magazine, Winter 2012.

Reuben, Julie A. The Making of the Modern University: Intellectual Transformation and the Marginalization of Morality. Chicago: University of Chicago Press, I992.

Schroth, Raymond A., S.J. Fordham: A History and Memoir. Chicago: Loyola Press, 2002. 